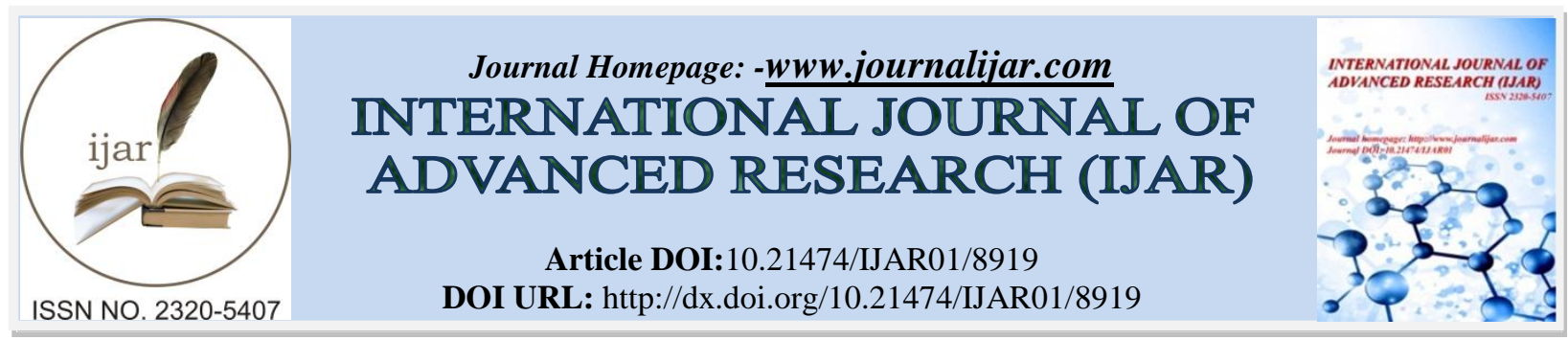

RESEARCH ARTICLE

\title{
EFFECT OF GROUP COUNSELLING IN REDUCING EXAMINATION MALPRACTICE TENDENCY AMONG SECONDARY SCHOOL STUDENTS IN IMO STATE, NIGERIA
}

\author{
Oguzie, Alphonsus Ekejiuba ${ }^{1}$, Oguzie,Mirian Nkechi $^{2}$, Nnadi, Grace Chinyere ${ }^{3}$, Mokwelu, Obianuju \\ Blessing $^{4}$, and Obi, Joy Sylvia $(\mathbf{P h D})^{5}$. \\ 1. Department of Guidance and Counselling, Nnamdi Azikiwe University, Awka, Anambra State, Nigeria. \\ 2. Community School Umuenyi, Isiala Mbana Local Government Area, Imo State, Nigeria.
}

\section{Manuscript Info}

\section{Manuscript History}

Received: 20 February 2019

Final Accepted: 22 March 2019

Published: April 2019

Key words:-

Group Counselling, Examination,

Malpractice, Tendency, Secondary

School.

\section{Abstract}

This study investigated the effect of group counselling in reducing examination malpractice tendency among secondary school students in Imo state, Nigeria. Two research questions were answered and two null hypotheses tested at 0.05 level of significance guided the study. The pre-test post-test control group quasi-experimental design was adopted for the study. The target population of the study was 2326 (1096male and 1230female) SS2 students that had examination malpractice tendency in all public secondary schools in Ngor-Opkala Local Government Area of Imo State as identified through their pre-test scores. The sample of this study consisted of eighty-four (84) students from two co-educational secondary schools selected through purposive sampling technique.Students Examination Malpractice Tendency Questionnaire (SEMTQ) was the instrument used for data collection. Data collected from the study were analysed using mean and ANCOVA. Results obtained from the study revealed that group counselling was significantly effective in reducing examination malpractice tendency among the participants. The results also indicated that group counselling was more effective in reducing examination malpractice tendency among female students than their male counterpart. The researchers recommended among others, that Guidance Counsellors should adopt group counselling as an effective intervention strategy in fighting the menace of examination malpractice in secondary schools, and that the government should provide school counsellors with proper in-service training programmes to enable them acquire adequate group counselling kills in other to discharge their duties more effectively.

Copy Right, IJAR, 2019,. All rights reserved.

\section{Introduction:-}

In all nations of the world, education has been identified and recognized as a strong pillar upon which the social, economic, political and technological advancement of the society depends. Education has also been well acknowledged as a vital medium for empowering the citizens morally and intellectually so as to produce individuals 
of worthwhile personality with relevant skills, aptitudes and competences needed for national growth and sustainable development. This therefore accentuates the generally accepted axiom that "no society or nation can develop more than the level and standard of education of her citizens". Little wonder the Federal Republic of Nigeria categorically emphasized on education as an instrument for national development and social change (FRN, 2013). Nevertheless, for education to achieve its apparent noble goals, adequate teaching and learning must take place and the feedback, outcome or success of such teaching and learning processes are usually assessed through examinations.

Significantly, to ensure the validity and acceptability of examinations results, all stakeholders (including students) are expected to adhere strictly to the rules and regulations guiding such examinations. Therefore, any misconduct or irregularity by students, another person or group of persons before, during and/or after examinations may distort this feedback mechanism and give a false outcome of the teaching and learning process, thereby amounting to examination malpractice. Unfortunately, common observation has shown that many Nigerian students indulge in various forms of examination malpractice.

Examination malpractice is defined as any dishonesty in examinations perpetrated by a person or a group of persons. It is an academic dishonesty involving any act of omission or commission which compromises the reliability of any assessment or evaluation system (Muhney et al., 2008). According to Anyamene et al., (2015), examination malpractice is defined as anything done by an examination candidate, examination administrator, teacher, parent or any person, that goes against stipulated examination ethics and laws. Barituka and Onyekuru (2017) viewed examination malpractice as an illegal or unethical behaviour by somebody in the process of testing the ability or knowledge of an examinee by means of questions. In addition, Oko and Adie (2016) noted that any deliberate act of wrong doing, contrary to the rules of examination designed to give a candidate an undue advantage amounts to examination malpractice. However, in the context of this study, examination malpractice is defined any kind of irrational behaviour exhibited by any person or group of persons before, during or after an examination which contravenes the rules and regulations governing the conducts of such examination. It is an illegal or unethical behaviour by anybody in the process of testing the ability or knowledge of a candidate.In the other hand, examination malpractice tendency for the purpose of this study is defined as the predisposition to indulge in examination malpractice. Benedette et al., (2012) lamented that examination malpractice is a pervasive problem in education and the extent to which secondary school students engage in the act has greatly increased.

Examination malpractice may take several forms. For instance, Owuamanam (2005) observed that examination malpractice may be in forms such as misrepresentation of identity or impersonation, cheating, theft of other students' work, tampering with the works of others, bringing prepared answers to examination halls, unethical use of academic resources, fabrication of results and showing disregard to academic regulations. Similarly, Alutu and Aluede (2006) noted that some forms of examination malpractice include examination leakage, impersonation, cheating, collusion, swapping of scripts, smuggling of answer scripts in examination halls, result/certificate forgery, verbal or physical assault on examination administrators. Moreover, common observation shows that female students sometimes trade their bodies in exchange for higher grades.

Furthermore, previous researchers have identified the causes of examination malpractice to include bad parental upbringing, fear of failure, craze for certificate, desire of parents to have their children in choice professions and university, pressure on students to pursue courses which they have no aptitude, pressure on teachers who want to gain favour of students and overcrowded sitting arrangement, lack of effective supervision and monitoring, rapid growth and demand for education, lack of viable teaching aids/infrastructure like standard laboratories and libraries, inadequate qualified manpower, among others (Akaranga and Ongong, 2013; CWO Voice, 2010; Petters and Okon, 2013). George and Ukpong (2013) attributed the increasing rate of examination malpractice to poor teaching, ineffective preparation by students, ill-equipped library facilities, and dubious admission policy. Literature has also indicated that examination malpractice among students is as a result of anxiety, laziness, poor study behaviour, negative peer influence, poor self efficacy, low self esteem, and corruption (Adeyemi, 2010; Ugwu, 2008). Examination malpractice is also caused by general moral decadence in the society. Common observation shows that nowadays, high premium is been placed on academic qualifications rather than practical capability.

Consequently, the overdependence on certificates as a measure of one's knowledge and competence may lead to undue overzealousness by students and their parents to acquire certificates through corrupt means which could make students susceptible to examination malpractice. Regrettably, it has become a common culture that people lay undue 
emphasis on success without laying corresponding emphasis on legitimate means of achieving such success. The aphorism "dignity for labour" is becoming a thing of the past in the contemporary Nigerian society. It is on this note, that Alutu and Aluede (2006) bewailed that the general emphasis in our society today is on materialism, bribery, corruption, cultism, sexual promiscuity, fraud, violence, certificate racketeering and a host of other social vices. All these could pose severe threat to the peace and tranquillity of the general society.

Therefore, examination malpractice like a wild wind that blows no one any good can cause severe negative effects to the academic, social, economic and psychological wellbeing of students, parents, teachers and the society in general. For instance, Oninye and Alawaye (2008) emphasized that examination malpractice may lead to cancellation of entire results which could cause great economic loss to parents and caregivers, and brings sources of great agony and injustices to innocent students. Withholding and cancellation of students' examination results which are some penalties accruable to examination malpractice may also lead to total withdrawal from school, delinquent behaviours, substance abuse, and depression, which could be detrimental to societal peace and security. On the long run, examination malpractice could distort the validity and reliability of examination results and hamper the achievement of educational goals and objectives, thereby fettering the social, political, technological, and economic growth and development of the nation.

Unarguably, examination malpractice is an express reflection of the decay in social norms and values that have succeeded in destroying the very foundation of education and thus must be confronted head on. More worrisome is the fact that examination malpractice has become an epidemic that cuts across every stratum of the Nigerian educational system, starting from Primary, through Secondary, to University levels. Although examination malpractice is neither a recent phenomenon nor a peculiar issue to Nigeria (Anzene, 2014), the alarming rate of its increase in Nigeria, particularly in Imo state, calls for novel intervention strategies such as group counselling to redress the situation.

Group counselling is defined as a process of interaction that occurs in a large group that facilitates the development of healthy attitudes and behaviours in a way that individuals who participate in it may gain new information and orientation to problems such as social, vocational and academic problems (Anagbogu, 2005). According to Survey (2012), group counselling is a form of therapy where people with similar experiences or issues come together with a professional therapist. Akpama (2013) viewed group counselling as a therapy carried out between a therapist and a group of people sharing the same problem or condition. Ncheke (2016) opined that group counselling is made up of normal individuals with varying concerns who are given all understanding, care, respect and support to help them either to learn or unlearn certain attitudes or behaviours. However, group counselling in the context of this study is defined as a helping process in which a professional counsellor is involved in a counselling relationship with a number of counsellees who share the same or similar challenges at the same time. Group counselling is problemoriented and remedial in nature. One of the main goals of group counselling is to enable members gain proper insight into their own thoughts and behaviours, and proffer solutions and support to other members.

Most interestingly, group counselling helps counsellees explore and confront specific life dissatisfactions by enabling them gain deeper understanding of their concerns, discover and implement effective ways of resolving such concerns. Group counselling operates on the principle of freedom of expression and uses group interaction to facilitate evaluation, self-understanding and self capacity. During group counselling, the counsellor's major role is to facilitate group interaction and cohesion through effective communication and unconditional positive regard. Opinions vary among scholars on the reasonable number of counsellees to be engaged in a particular group counselling programme at a time. For instance, Iwuama (1999) suggested about four to twelve counsellees, while Ekwe and Nwamuo (2000) preferred about four to ten counsellees. To Okeke (2002) group counselling is better carried out with about fifteen to twenty or more counsellees at a time. However, the present researchers are of the opinion that the number of counsellees to be engaged in a group counselling process should be determined by the counsellor's level of experience, skills, competence and ingenuity, coupled with the nature of counsellees' problem. Many researchers have attested to the effectiveness of group counselling on behaviour problems among students (Weiss et al., 2007; Akpama, 2013; Dortaj et al., 2013; Badrkhani, 2015; Ncheke, 2016).

Moreso, the effect of group counselling on behaviour problems among students has been found to be moderated by gender. For instance, Hanshaw (2001) observed that male students benefited more from group counselling than female students. Similarly, Igbwe (2013) observed that male students benefited more from group counselling than their females counterpart. In contrary, Akpama (2013) found that group counselling was significantly effective on 
female students than their male counterpart. However, Ncheke (2016) in his study concluded that there is no significant difference in the effect of group counselling based on gender. Despite the high premium placed on examinations by the National Policy on Education, (FGN, 2013) and the measures put in place to cub examination malpractice in the Nigerian educational system, the menace still remains ever-increasing and a major source of concern to stakeholders. Against this backdrop, the present study determined the effect of group counselling in reducing examination malpractice tendency among secondary school students in Imo State, Nigeria.

\section{Research Questions}

The study was guided by the following research questions:

1. What are the differences between the Pre-test and Post-test examination malpractice tendency mean scores of students treated with group counselling and those in the control group?

2. What are the differences between the Pre-test and Post-test examination malpractice tendency mean scores of male and female students treated with group counselling?

\section{Hypotheses}

The following null hypotheses were tested at 0.05 level of significance:

1. There is no significant difference between the Pre-test and Post-test examination malpractice tendency mean scores of students treated with group counselling and those in the control group.

2. There is no significant difference between the Pre-test and Post-test examination malpractice tendency mean scores of male and female students treated with group counselling.

\section{Method:-}

This study adopted the pre-test-post-test control group quasi-experimental research design. The design is so called because it does not employ randomization in the placement of participants into experimental and control groups. Harrington and Harrington (2006) described a quasi experimental study as a type of experimental study which determines the effect of a treatment paradigm on a non randomized sample.

Fig 1:-A non-randomised pre-test and post-test control group design

\begin{tabular}{|lccc|}
\hline Group & Pre-test & Research condition & Post-test \\
\hline Experimental & $\mathrm{O}_{1}$ & $\mathrm{X}$ (treatment $(\mathrm{GC})$ & $\mathrm{O}_{2}$ \\
Control & $\mathrm{O}_{1}$ & $\mathrm{X}_{0}$ (no treatment) & $\mathrm{O}_{2}$ \\
\hline
\end{tabular}

$\mathrm{O}_{1}$ stands for the pre-test (initial observation) which was administered to all the participants.

$\mathrm{X}_{1}$ stands for the treatment (group counselling) which was administered to the experimental group only.

$\mathrm{X}_{0}$ signifies that no treatment was given to the control group.

$\mathrm{O}_{2}$ stands for the post-test (final observation) which was administered to both the experimental and control groups.

The study was conducted among senior secondary school students in Imo state. The target population of the study was 2326 (1096male and 1230female) SS2 students that have examination malpractice tendency in all public secondary schools in Ngor-Opkala Local Government Area of Imo State as identified through their pre-test scores. Purposive sampling was used to select eighty-four (84) students from two co-educational secondary schools that had the largest number of students with examination malpractice tendency. Thus, 43(20male and 23female) students formed the experimental group, while 41(19male and 22female) students formed the control group.

The instrument used for data collection was a twenty-five (25) item structured questionnaire titled; Students Examination Malpractice Tendency Questionnaire (SEMTQ). The SEMTQ used in this study comprised two sections A and B. Section A was an introductory part that solicited the bio-data of the respondents such as gender, while section B was designed to detect students with examination malpractice tendency. The instrument was face validated by three experts in Nnamdi Azikiwe University, Awka and Alvan Ikoku Federal College of Education, Owerri. The reliability of the instrument was ascertained by conducting a pilot study using the test-retest method which yielded a correlation coefficient $\mathrm{r}=0.79$. The participants were pre-tested with the instrument before the experiment. Students in the experimental group received group counselling while students in the control group did not receive any treatment. At the end of the experiment, the participants were post-tested by re-administering a reshuffled form of the SEMTQ. All data collected for this study were organised in tables and analysed. Mean was used to answer the research questions while Analysis of covariance (ANCOVA) was used to test the null hypotheses 0.05 level of significance. 


\section{Results:-}

Table 1:-Pretest and Posttest examination malpractice tendency mean scores of students treated with group counselling and those in the control group (Norm $=62.50$ )

\begin{tabular}{|lccrrc|}
\hline Source of Variation & $\mathrm{N}$ & Pretest Mean & Posttest Mean & Rdn. in Mean & Remark \\
\hline Group Counselling & 43 & 97.24 & 39.08 & 58.16 & Effective \\
\hline Control & 41 & 88.69 & 84.91 & 3.78 & \\
\hline
\end{tabular}

In table 1, it was observed that the students in experimental group had a pre-test mean score of 97.24 and a post-test mean score of 39.08, with a reduction in mean score of 58.16 in their examination malpractice tendency, while those in the control group had a pre-test mean score of 88.69 and a post-test mean score of 84.91 with a reduction in mean score of 3.78. With a post-test mean score of 39.08 which is below the norm of 62.50 , group counselling was effective in reducing secondary school students' examination malpractice tendency.

Table 2:-Pretest and Posttest examination malpractice tendency mean scores of male and female students treated with group counselling

\begin{tabular}{|lrrrrr|}
\hline Source of Variation & $\mathrm{N}$ & Pretest Mean & Posttest Mean & Rdn. in Mean & Remark \\
\hline Male & 20 & 90.89 & 42.67 & 48.22 & \\
\hline Female & 23 & 95.22 & 31.32 & 63.90 & More effec tive \\
\hline
\end{tabular}

Table 2 revealed that male students treated with group counselling had a pre-test mean score of 90.89 and a post-test mean score of 42.67 with a reduction in mean score of 48.22 , while female students in the group had a pre-test mean score of 95.22 and a post-test mean score of 31.32 with a reduction in mean score of 63.90. Therefore, group counselling was more effective in reducing male students' examination malpractice tendency than their male counterpart.

Table 3:-ANCOVA on the posttest examination malpractice tendency mean scores of students treated with group counselling and those in the control group.

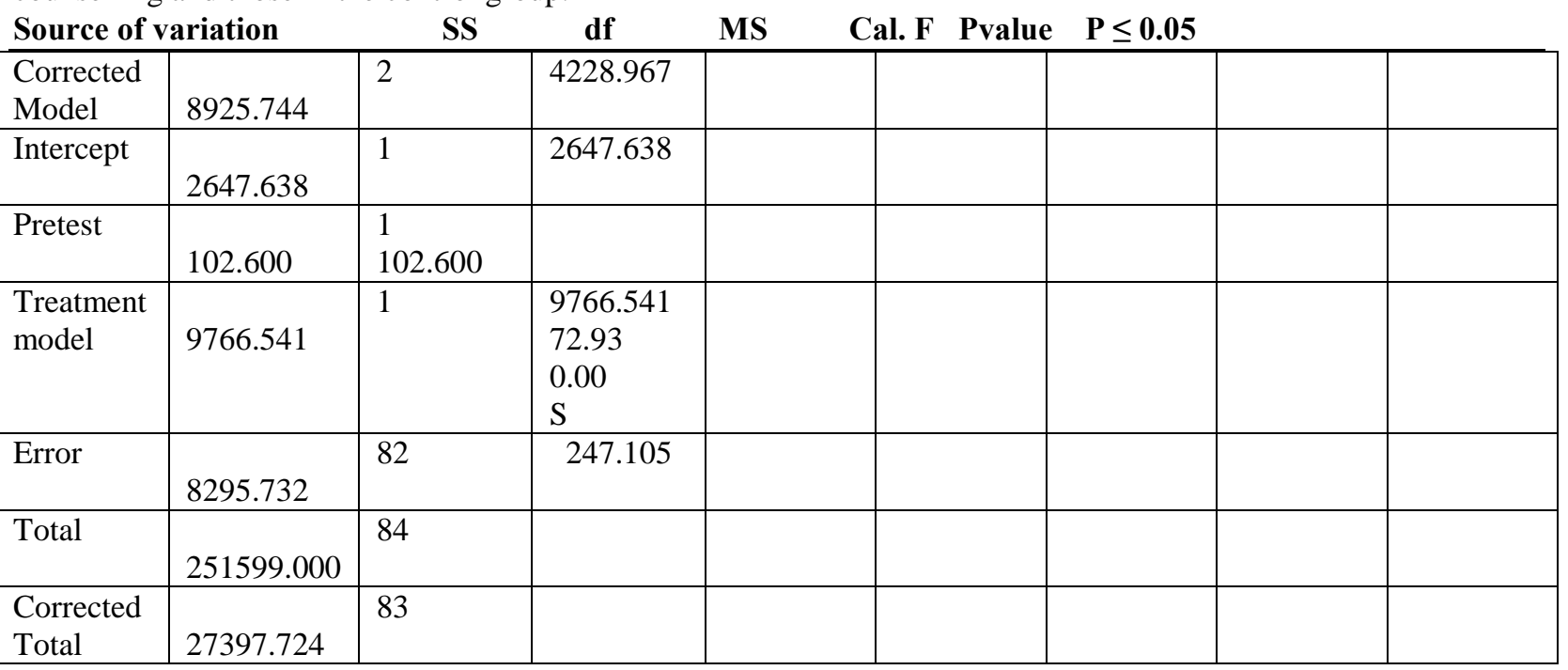

Table 3 indicated that at 0.05 level of significance, $1 \mathrm{df}$ numerator and $83 \mathrm{df}$ denominator, the calculated $\mathrm{F}$ is 72.93 with Pvalue of 0.00 which is less than 0.05 . Therefore, the first null hypothesis is rejected. This indicates that the effect of group counselling in reducing examination malpractice tendency among the secondary school students was significant.

Table 4:-ANCOVA on the posttest examination malpractice tendency mean scores of male and female students treated with group counselling

\begin{tabular}{|lrrllll|}
\hline Source of variation & SS & df & MS & Cal. F & Pvalue & P $\leq \mathbf{0 . 0 5}$ \\
\hline Corrected Model & 371.906 & 2 & 81.944 & & & \\
\hline
\end{tabular}




\begin{tabular}{|lrlrlll|}
\hline Intercept & 233.149 & 1 & 233.149 & & & \\
\hline Pretest & 815.117 & 1 & 815.117 & & & \\
\hline Gender & 17.328 & 1 & 17.328 & 35.10 & 0.00 & $\mathrm{~S}$ \\
\hline Error & 2409.439 & 41 & 96.645 & & & \\
\hline Total & 15862.000 & 43 & & & & \\
\hline Corrected Total & 3907.261 & 42 & & & \\
\hline
\end{tabular}

Table 4 shows that at 0.05 level of significance, $1 \mathrm{df}$ numerator and $42 \mathrm{df}$ denominator, the calculated $\mathrm{F}$ is 35.10 with Pvalue of 0.00 which is less than 0.05 . Therefore, the second null hypothesis is rejected. So, the difference in the effect of group counselling in reducing examination malpractice tendency among the male and female secondary school students is significant.

\section{Discussion:-}

This study examined the effect of group counselling in reducing examination malpractice tendency among secondary school students in Imo state, Nigeria. From the analysis carried out in this study, the results revealed that group counselling is significantly effective in reducing examination malpractice tendency among the students who participated in the experiment. Specifically, the result indicated that the students had high tendency towards examination malpractice as evidenced in their pre-test scores, but there was a significant reduction in their post-test scores. The overall result therefore indicated that students who were exposed to group counselling experiment benefited greatly in the exercise. This finding is in line with the report of previous researchers (Weiss et al., 2007; Akpama, 2013; Dortaj et al., 2013; Badrkhani, 2015; Ncheke, 2016). Anagbogu (2005) noted that group counselling is a process of interaction that occurs in a large group that facilitates the development of healthy attitudes and behaviour in a way that individuals who participate in it may gain new information and orientation to problems such as social, vocational and academic problems. This could have been the reason why the students who participated in the group counselling experiment recorded significant decrease in their examination malpractice tendency. Perhaps through the social interaction platform provided by group counselling during the experiment the students have gained better irrational thought, and this may have enabled them adopt rational and legitimate ways of achieving success in examinations. As students develop more rational and legal means of securing academic success, their tendency towards examination malpractice reduces infinitesimally.

Another finding of this study revealed that there is significant difference in the effect of group counselling in reducing examination malpractice tendency among the students based on gender. The second result of this study indicated that female students who participated in the group counselling experiment had a greater reduction in mean than the male students. This signifies that the female students benefited more from group counselling than their male counterpart. This finding is in accordance with the study of Akpama (2013) which indicated that female students benefited more from group counselling than the male students. However, the finding contradicts the reports of other researchers (Hanshaw, 2001; Igbwe, 2013) who found that male students benefited more from group counselling experiment than female students. This finding equally refuted the report of Ncheke (2016) which concluded that there is no significant difference in the effect of group counselling based on gender. The controversy in the findings about gender difference in the effect of group counselling as observed above may be as a result of difference in researchers' ingenuity, methodology, instrumentation or location. It is very important to note that if the necessary extraneous variables are not properly controlled during a study, they could mar the results of a research study. Moreso, the validity and reliability of instrument(s) for data collection, coupled with the accuracy of data analysis may greatly determine the validity of the results of a research study.

\section{Conclusion:-}

Based on the results of the study and the discussions that followed, it was concluded that group counselling is effective in reducing examination malpractice tendency among secondary school students. Moreover, it was also concluded that group counselling was more effective in reducing examination malpractice tendency among female students than their male counterparts.

\section{Recommendations}

Based on the findings of the study, the researchers made the following recommendations:

1. That Guidance Counsellors should adopt group counselling as an effective intervention strategy in fighting the menace of examination malpractice in secondary schools. 
2. That secondary school students should be properly engaged in group counselling programmes prior to their examination period.

3. That students with examination malpractice tendency should be immediately referred to the school-based counsellors by teachers and other staff.

4. That the government should provide school counsellors with proper in-service training programmes to enable them acquire adequate group counselling kills in other to discharge their duties more effectively.

5. That since parents, caregivers and teachers are the major custodians of the students, there is need to carry out pragmatic group counselling programmes on these groups of stakeholders so as to re-orientate their irrational thoughts and beliefs about examinations.

\section{References:-}

1. Adeyemi, T.O. (2010): Examination malpractices among secondary school students in Ondo State, Nigeria: Perceived causes and possible solutions. J. Edu. Admin. and Poli. Stu., 2(3): 48-55.

2. Akaranga, S.I. and Ongong, J.J. (2013): The phenomenon of examination malpractice: An example of Nairobi and Kenyatta Universities. J. Edu and Pract., 4(18): 87-96.

3. Akpama, E.M. (2013): Effect of group counselling on the adjustment pattern of people living with HIV/AIDS in Cross River State. J. Edu. Soc. Research., 3(2): 377-385.

4. Alutu, A.G. and Aluede, O. (2006): Secondary schools student's perception of examination malpractices and examination ethics. J. Hum. Ecol., 20(4): 295-300.

5. Anagbogu, M.A. (2005): Foundation of guidance and counselling for Universities and Colleges. ( $\left.2^{\text {nd }} E d\right)$. Enugu: Academic Publishing Company.

6. Anyamene, A., Nwokolo, C. and Maduegbuna, U. (2015): Effects of psycho-educational technique on examination misconduct tendencies of secondary school students in Anambra State. Europ. Sci. J., 11(11): 148169.

7. Anzene, S.J. (2014): Trends in examination malpractice in Nigerian educational system and its effects on the socio-economic development of Nigeria. Asian J. Hum. Soc. Sci., 2(3): 1-8.

8. Badrkhani, M. (2015): The effectiveness of group counselling in increasing the social adjustment of students in Tehran. J. Edu. Manag. Stu., 5(1): 34-40.

9. Barituka, K.M. and Onyekuru, B.U. (2017): Parenting styles as correlates of students' attitude towards examination malpractices in Obio/Akpor local government area of Rivers State: Implications for counselling. British J. Edu., 5(5): 60-71.

10. Benedette, U., Corneliu, U., Ndifon, R.A. and Obinna I.E. (2012): Correlates of examination malpractice and academic performance of primary school students in Cross River State. American J. Soc. Iss. Hum., 2(6): 398405.

11. Dortaj, F., Shakiba, M. and Shakiba, J. (2013): The effect of cognitive behavioural group counselling on social coping of crack abusers. Zah. J. Res. Med. Scies, 15(2): 59-63.

12. Ekwe, T. and Nwamuo, P. (2000): A practical approach to group guidance and counselling. Owerri: Joe Mankpa Publishers.

13. Federal Republic of Nigeria. (2013): National policy on education $\left(6^{\text {th }}\right.$ ed. $)$. Lagos: NERDC Press.

14. George, I.N. and Ukpong, D.E. (2013): Contemporary social problems in nigeria and its impact on national development: implication for guidance and counselling services. J. Edu. Soc. Res, 3(2): 167-173.

15. Hanshaw, C.J. (2001): Effect of group counselling on academic performance of secondary school students in Enugu State. (Unpublished Masters thesis). University of Lagos, Lagos State.

16. Harrington, H. and Harrington, C. (2006): Research and theory to research all learners. Retrieved from www.ideas.respec.org.

17. Igbwe, E.U. (2013): Effects of individual and group counselling on students' truant behaviour in Abia State. Ethio. Inter. Multi. J., 7(2): 277-293.

18. Iwuama, B.C. (1999): Foundations of guidance and counselling. Owerri: Joe Mankpa Publishers.

19. Muhney, K.A, Gutmann M.E. and Schniedeman E. (2008): The prevalence of academic dishonesty in texas dental hygiene programme. J. Dent. Edu., 7(11): 1247-1260.

20. Ncheke, D.C. (2016): Effect of group counselling on enhancing school adjustment of social isolates. The Edu Pych, 10(1): 54-58.

21. Okeke, B.A. (2002): Techniques and practicum in guidance and counselling. Enugu: Snaap Press.

22. Oko, S.U. and Adie, R.I. (2016): Examination malpractice: Causes, effects and possible ways of curbing the menace. Inter. J. Manag. Stu. Res., 4(1): 59-65 
23. Oninye, A.O. and Alawaye, A.S. (2008): Female students' perceived causes of and solutions to examination malpractice in Asa local government: Implication for counselling. Soko. Edu. Rev, 10(2): 45-57.

24. Owuamanam, D.O. (2005): Ethics and professionalism in academics. Paper presented at the Faculty of Education Seminar, University of Ado-Ekiti, Nigeria on 16th May, 2-7.

25. Petters, J.S., and Okon, M.O. (2013): Students' perception of causes and effects of examination malpractice in the Nigerian educational system: The way forward for quality education. Retrieved from www.sciencedirect.com/science/article/pii/S187704 281305310X

26. Survey, M. (2012): Effect of group counselling on students' social and psychological adjustment. Retrieved from http:/www.ceorachout.com>types-of-therapy

27. Ugwu, C. (2008): The menace of examination malpractice. Retrieved from http://www.feathersproject.wordpress.com/2008/...

28. Weiss, R.D., Graffin, M.L. and Kolodziej, M.E. (2007): A randomized trail of integrated group therapy versus group drug counselling for patients with bipolar disorder and substance dependence. American J. Psychry, 164(1): 100-107. 